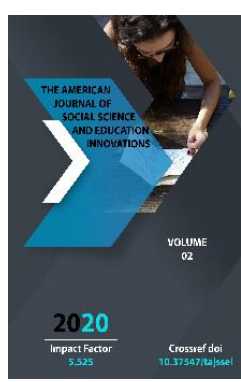

Copyright: Original content from this work may be used under the terms of the creative commons attributes 4.0 licence.

\section{Abu Nasr Farobi's Scientific Heritage, Views On The Establishment Of A Spiritual And Democratic Society}

\author{
Kamolova Nodira Akrambekovna \\ Master, Named After Nizami TSPU, Tashkent, Uzbekistan \\ Ibragimova Dilnoza Rashid qizi \\ Master, Named After Nizami TSPU, Tashkent, Uzbekistan
}

\title{
ABSTRACT
}

This article analyzes the scientific heritage of Abu Nasr al-Farabi, a leading thinker of the Central Asian Renaissance, his views on building a spiritual, moral and democratic society, and his exemplary views on education.

\section{KEYWORDS}

Pharoah, encyclopedic scientist, morality, education, upbringing, psyche, being, knowledge, ability, views, spiritual views, classification of sciences, imagination, perception, understanding, cause, consequence, being, element, form, content, democratic society, justice.

\section{INTRODUCTION}

Different scientists have emerged from Central Asia at different times. They have made great discoveries in the field of science in which they have dealt with, and have been able to conquer the radiant peaks of science that no scientist of their predecessors has conquered. In addition, many of them invented new directions in science, new ways of thinking, introduced completely new doctrines that no one had said before, and provided a scientific basis. The profoundly scientifically based ideas and teachings of great thinkers are invaluable not 
only in terms of the period in which they lived, but also in terms of predicting the future, predicting natural, social events and processes. The scientific and philosophical teachings of our wise forefathers are the teachings of universal significance. It is noteworthy that the thinkers of the East were at the center of the current life of their time, defending the interests of the people and the Motherland. This is the sign and the main reason that they are truly harmonious human beings, fiery patriots, nationalists and great scholars. From the time when these great people lived and created encyclopedic minds, science, culture and philosophy began to develop in the East and Central Asia. This development, the continuous improvement, spanned hundreds of years and has reached our time.

If we study the scientific heritage of Al-Farabi as one of the great scholars and representatives of the Central Asian Renaissance, he covered almost all fields of science and passed on to future generations a great spiritual heritage through more than 160 works in various fields. left. Farobi was famous throughout the Muslim world at the time for writing great works and treatises on mathematics, astronomy, medicine, music, philosophy, linguistics and literature. He wrote Aristotle's "On the Purposes of Metaphysics," "On the Members of Living Beings," "The Book of Music," "On the Achievement of Happiness," "The City of Noble People," "The Book of Laws," and many others. testifies to the incomparable breadth and depth of the scientist's level of knowledge and worldview. For his great contribution to the development of science, Farobi received the prestigious titles of "Al-Muallim as-Sani" - "The Second Teacher", "Aristotle of the East".
Farobi's treatise On the Organs of the Human Body is devoted to defining the goals and objectives of medical science, and the encyclopedic scholar Ibn Sina also referred to this work. In this sense, this work proves that Farobi was a great encyclopedist.

In his pamphlet On the Right and Wrong Rules of Astrology, Farobi emphasizes the need to distinguish between the activities of astrologers based on scientific assumptions about celestial bodies and mental and social phenomena and processes, as well as false assumptions and myths.

The scholar's multi-volume book, The Great Book of Music, proves not only that he was a great scholar of music, but also that Farobi was a well-known musicologist, musician, and composer. He was also the inventor of a new musical instrument. Farobi is also known as a great logician. In this regard, he continued the positive traditions of Greek scholars and wrote a number of pamphlets on various problems of the science of logic.

\section{METHODS}

Comparative, analytical, scientific, historical, and philosophical research methods were used to illuminate Abu Nasr Faroobi's views on scientific heritage, spirituality, and the building of a democratic society.

The development and progress of medieval science The scientific and creative work of Farobi on the classification of sciences is invaluable. In his pamphlets On the Origin of the Sciences and On the Classification of the Sciences, he gives an order, classification, and detail of about 30 branches of science known at that time. In general, Farobi outlines five main categories of science: 
1. The science of language (grammar, poetics, spelling, etc.). It consists of seven sections).

2. Logic. It consists of eight sections.

3. Mathematics, seven independent sciences: arithmetic, geometry, optics, planets, music, gravity, mechanics.

4. IIm at-natural and ilm al-divine - natural and divine sciences or metaphysics.

5. Political science (cultural science, urban science, urban management), jurisprudence (figh) and Muslim theology (kalam).

Every field in which Farobi was engaged, every work he wrote, was praised and admired by scholars of the new era and modern times. Farobi's works cover almost all areas of medieval science. That is why his works can be called a mirror, an encyclopedia of his time. Farobi created special works by scientifically analyzing the general content and direction of the major works of ancient Greek thinkers and naturalists. He commented on Aristotle's Metaphysics, Rhetoric, Poetics, Categories, Analytics, Ethics, and many others. Farobi made a great contribution to the development of medieval philosophy, being the first to classify the sciences of his time, that is, to divide them into species. In addition to his native language, Turkish, he is fluent in Persian, Greek, Syriac, Arabic and several other languages. According to Ibn Hallikan (12111282), a well-known historian of the East, no one has reached the level of Farobi in linguistics. According to him, Farobi knew more than seventy languages. Farobi became so famous for his knowledge, enlightenment, breadth of thought, encyclopedia, invaluable contribution to the development of world science that he became a great thinker after
Aristotle in his lifetime, "Al-Muallim as-Sani" "Second teacher"," Aristotle of the East".

The famous Renaissance philosopher Pharoah described God as "the first cause, the" first essence. " Pharoah derives all existence, the universe, the first cause - philosophy from God. He asserted that the material basis of the world consists of earth, water, air, fire and heaven, and that according to the teachings of Farobi, both celestial bodies and terrestrial bodies are formed from the combination of these elements. Farobi says that the common denominator of everything is the universe, that there is nothing but the universe.

Pharoah also states that everything in the universe is made up of matter and form, that matter and form cannot cause each other, but that both are in a dialectical unity with each other.

According to the scholar, motion is the constant movement and change of things and events in the material world, and the reason for the movement and growth is the various addition of the primary material elements.

Farobi's views on cognition are also noteworthy. He views the question of knowledge as a component of the explanation of human nature. It is the product of human development, different from the animal world, and nature is its object. He says that what is known exists before he knows, just as the object exists before the subject. The book The Virtues of Science and Art emphasizes the infinity of knowing nature, the process of knowing from ignorance to knowledge, from knowing causation to knowing consequences.

Farobi cognition can be divided into emotional and mental cognition in two stages. He sees emotional cognition as a source of knowledge 
about the external properties of being. At the same time, he argues that mental cognition cannot come into being without emotional cognition. Man learns the material world around him, the matter, through his senses, his intellect. In his works, Farobi argues that the human brain controls cognition and mental abilities, and the heart provides all the organs with the blood necessary for life, and that none of these energies can survive without matter. Farobi's services are extremely important in substantiating serious issues such as the origin of the term dialectics, its essence, its importance in the formation of the art of philosophical thinking, its importance in scientific knowledge, its difference from sophistic thinking.

Farobi is the scientist who substantiated the interdependence of the categories of possibility and reality, necessity and chance, cause and effect. He argues that cause and effect are inextricably linked, that a particular cause leads to a certain consequence, and that chance is a manifestation of necessity. It is clear from this that Farobi's main focus in the study of forms and methods of thinking has been to reveal the dialectical connection and interdependence between these concepts. In short, the scientific and philosophical heritage of Farobi has served as a great spiritual wealth of our people for centuries as a source of inspiration and creativity for those generations.

Pharoah divides human abilities into two: innate and acquired. According to him, innate ability includes biological, physical and some mental characteristics. The process of its development takes place throughout one's life through the study of science, profession, the acquisition of moral principles, and the enrichment of art with life experience. These qualities, including aesthetic qualities, are formed under the influence of the human environment. Farobi emphasizes the role of poetry and music in the self-education and aesthetic development of man. According to him, all types of art are different: the art of poetry works with words, and the fine arts work with paints, but they have the same effect on a person. He follows in Aristotle's footsteps and argues that both of these arts aim to influence people's imaginations and emotions through imitation.

Farobi understood that art was, by its very nature, a reflection of spiritual life. According to him, music has a great impact on people's emotions. This science is useful in the sense that it regulates the behavior of (people) who have lost their balance, perfects imperfect behavior, and maintains the balance of the behavior of people who are in balance, "he says. "This science is also good for the health of the body," Farobi said, noting the healing power of music. Farobi became famous as a great medieval musicologist with his multivolume work, The Great Book of Music. He divides them into definitions and sciences, taking into account the theoretical and practical branches of musicology, the internal structure and laws of melodies. He not only gives natural-scientific descriptions of the formation of sounds in music theory, but also reveals the mathematical principles of melody, gives many complex drawings based on various tables, rules of geometry, explains Eastern music, the basics of its rhythms with evidence. The thinker's theory of rhythm is based on the pronunciation of words that are fast or slow, unaccented or conditionally accepted. He described the movements that are the units that make up the rhythm, the measurements and types of rhythm that are 
created based on the variety of corners that are formed from their combination.

The Great Book of Music not only describes the theory and history of music, but also the musical instruments known in the East, such as the rubab, the tanbur, the nagara, the ud, the law, the nay, and the rules of melody. Farobi himself was a skilled musician, composer and inventor of new musical instruments. He made a narrow application to music that nurtured human morality, improved health, and enhanced the sound. Farobi's works on the theory of poetry and music have a special place in the history of literary and aesthetic views of the peoples of the East. Farobi's book, On the Achievement of Happiness, discusses the enormous power of art. According to him, art has the power to cultivate beautiful aesthetic qualities in a person. That is why the thinker places special demands on man. In this pamphlet, Farobi focuses on the issues of education and shows that it is the sacred duty of educators to educate young people in the rules of morality and practical skills for mastering the arts.

Farobi evaluates all human qualities as the beauty of people and things, and connects them with the aspects of purpose and usefulness. In his pamphlet On the Art of Poetry, he compares artistic activity to the imitation of reality in a unique way, and distinguishes between art and poetry in terms of words and paints, by imitating people's imaginations. 'aims to keep a secret, he says. This effect is called power, imagination, and it is between emotion and reason. In Farobi's aesthetic views, the images created by art do not show their individuality when perceived in the mind and general observation, but retain a clear emotional form that is possible for perception.

\section{RESULTS}

Abu Nasr al-Farabi pays great attention to the issue of education, especially mental education, enlightenment, enrichment of the mind with existing knowledge. Abu Nasr alFarabi emphasizes the idea that any education, especially mental education, that is, the study of knowledge, should begin at a young age. However, Abu Nasr al-Farabi did not limit his "intelligence" to intellectual training. According to Abu Nasr al-Farabi, "intelligence" is measured by the whole set of human activity - his knowledge, morals, manners, actions, deeds, that is, intelligence is the unity of all the qualities as a whole.

In the teachings of Abu Nasr al-Farabi, moral education is also an important condition for the education of intelligent, virtuous people, and mental education is reflected, in particular, in the work "Ideas of the people of the ideal city." He does not dwell on the order in which moral upbringing, in particular, what qualities of the child should be taken into account, but promotes the idea that it is necessary to emulate this image in the field of upbringing by creating an abstract image of an ideal, moral person. . Among these qualities, Abu Nasr alFarabi paid special attention to wisdom. Physical and mental qualities play an important role in the upbringing of an ideal person. He creates the ideal of man, both physically and morally, mature and perfect in all respects, by denouncing vile, filthy traits, exposing immoral persons, and contrasting them with noble moral qualities, and is the goal of any education. as an example.

Farobi's works reflect the problems of man, human upbringing, society and the state. Inspired by the ideas of free thinking, that is, the medieval philosopher Abu Nasr al-Farabi, 
the interrelationship between human existence, in particular his body and soul and his humanity, his humanity and the society in which he lives, tried to theoretically reveal the problems of the qualities, attributes that characterize humanity, and the process of their formation. Reflecting on the problems of the interrelationship of the soul and the body, Abu Nasr al-Farabi challenged the ancient Greek philosopher Plato's teaching on human migration. In his book The Essence of Matters, he put forward the idea that the soul does not exist before the body, nor can it move from one body to another. According to Abu Nasr alFarabi, with the appearance of the human body, its "nourishing power" is created. With that energy, the human body is constantly nourished, and in the process, the human senses are formed. The human senses combine imagination, memory, and imagination. Pharoah went against the rules of Islam, which said that man could not change his own destiny, and advanced the idea that man could change his own destiny. In particular, he tries to prove that human happiness is in his own hands. It seeks to identify ways to achieve happiness. According to him, in order to achieve happiness, a person must first have knowledge about happiness, and then know the ways and means to achieve happiness. It is also necessary for a person to understand the content and essence of human qualities in order to be happy. For example, the famous medieval anthropologist explained that "virtue" is not an abstract concept, but a special spiritual and moral feature of man, measured by his practical work in the process of becoming a human being. Virtue is an expression of a person's behavior in pursuit of goodness. According to Farobi, the spiritual and moral qualities that encourage a person to do good deeds and have good behavior are called qualities. Desires that encourage a person's bad behavior are called depravity. Razolat is an expression of a person's flaws or shortcomings.

\section{DISCUSSION}

Farobi calls on people to work together, to dream of creating a single human community in the world. In the book On Achieving Happiness, perfection cannot be achieved by one person alone, without the help of one or many others. "Every human being is structured by nature," says Farobi, "that he needs many things to live and attain a high level of maturity. He cannot achieve such things on his own. there is a need for a team. Therefore, it is only through the union of many people that are necessary for survival, that bring people together and help each other, that one can attain the maturity that one naturally strives for. The activities of the members of such a community as a whole provide each of them with the things they need to survive and mature.

An analysis of Abu Nasr al-Farabi's sociopolitical and moral views suggests that he was at the forefront of interpreting moral and political issues. The scientist thinks deeply about man and his qualities, thoughts, dreams and desires, and cares about the education of the younger generation.

Farobi sought to address social issues from a universal and humane perspective. In particular, his socio-utopian views, his ideas about a perfect community, a prosperous state, played an extremely positive role for that period. Such ideas were directed against medieval oppression and social injustice. Another noteworthy point of view of the thinker is that he considers all categories of people to be equal. In his works, he does not 
put one person above another, he does not discriminate against them. He argued that in a society where justice prevails, everyone is equal. Farobi's universal ideas played an important role not only in his time, but also in the formation of the worldview of scientists who lived in later times. During the 11th and 20th centuries, his pamphlets were copied many times, printed in lithographs, studied by scholars, and commented on.

\section{CONCLUSION}

It is worth noting the role of Abu Nasr Farobi's "City of Noble People" in our social life, as well as the importance of educating our youth as spiritually mature people. From the above, the following conclusions can be drawn:

- Abu Nasr al-Farabi was one of the first medieval Muslim philosophers to create a coherent doctrine of the origin of society, its goals and objectives;

- Reiterated the need to adhere to the principles of social justice and morality in the management of the community;

- Farobi reiterated the priority of the principles of social justice in all spheres to ensure the well-being of man and the people;

- The famous thinker analyzed all the good and bad social qualities of a person in order to study his spiritual image in a comprehensive way;

- Proved that it is impossible to know the level of formation of humanity in a person without defining the criteria for the expression of a person's social image, his good and bad habits, his actions;

Thus, Farobi dreamed of the establishment of a free, ideal state based on truth, humanity, emphasizing that the source of its achievement is the positive qualities and science in human beings. In general, Farobi is a famous medieval anthropologist. During the years of independent development, great changes have taken place in our country on the path to building the rule of law, a democratic society, a free and prosperous life. However, given that there are still problems, difficulties, misunderstandings, shortcomings and obstacles in this regard, we will identify ways to overcome them based on our past spiritual heritage, national and universal values, the history of our national statehood and mentality. we have to go. One of the spiritual foundations of a democratic society is a number of important factors. One of the most important factors is the cultural heritage, its objective attitude and care. Thus, the preservation of cultural heritage plays an important role in shaping a democratic society and determining its spiritual foundations. Reforming the worldview of our people in the spirit of national independence is one of the urgent tasks of our time. The issue of bringing up our children as worthy sons and daughters of a free and democratic Uzbekistan should be the main direction of our spiritual work.

The ideology and legitimacy of the pursuit of goodness and enlightenment must be instilled in the nature, blood and lineage of the nation. " President of the Republic of Uzbekistan IAKarimov said, "Everyone, nation, people want to know their history, so our scientists have a scientific concept of the historical past, identity, spirituality and culture of the Uzbek people. They need to create, "he said. "We know the people not by name, but by their culture, their spirituality, we look at the roots of their history." This fundamental instruction of the head of our state provides a basis for a deeper study of the life and work of Eastern 
thinkers and their effective and appropriate use in creating the foundations of a new society.

The study of the spiritual heritage of the people in Uzbekistan and a new approach to their importance in the life of society require proof on the basis of deep philosophical and scientific hypotheses that they are of great importance for the gradual development of society. Our country has always made an unforgettable contribution to the treasury of human thought, and for centuries the high spirituality, justice and other qualities of our people have been an example to all.

\section{REFERENCES}

1. Karimov I.A. Without historical memory, there is no future. - Tashkent : Uzbekistan, 1998.

2. Karimov I.A. On the way to spiritual growth. Tashkent .: Uzbekistan, 1995.

3. Karimov I.A. The ideology of national independence is the belief of the people and confidence in the great future. Volume 8 Tashkent.:Uzbekistan,2000.

4. Karimov I.A. Uzbekistan is moving towards the 21st century. Tashkent.:Uzbekistan,1999.

5. Khairullaev M.M. Farobi and his philosophical treatises.

Toshkent.:1963.

6. Khairullaev M.M. The second teacher. Tashkent.:1975.

7. Khairullaev M.M. Renaissance and Eastern thinker. T.:1971.

8. Khairullaev M.M. Eastern renaissance and Farobi. Science and life, Tashkent.:1975.

9. Abu Nasr Faroobi. Brochures. Toshkent.:Fan,1975.
10. Abu Nasr Faroobi. A city of noble people. -Tashkent.:Abdulla 